\title{
ANALISIS USAHATANI LABU KUNING DI DESA SINGSINGON RAYA, KECAMATAN PASSI TIMUR, KABUPATEN BOLAANG-MONGONDOW
}

\author{
Lina Tini Pendong \\ Oktavianus Porajouw \\ Lyndon R. J. Pangemanan
}

\begin{abstract}
ABSRACT
This study aims to analyze the cost and income of pumpkin farming in Singsingon Raya Village, East Passi District. The study was conducted from January to February 2017. The data used were primary and secondary data. Primary data through interviews using questionnaires to 15 respondents and secondary data obtained from Singsingon Raya Village Office. This analysis uses descriptive analysis. The results showed that the cost used for the largest pumpkin laboratory is labor cost and transportation cost of $87.28 \%$. In the marketing of pumpkin, farmers get large enough revenue so that farmers earn substantial income. The results can be seen from the total average production cost of $R p$ 4,012,238.00 / Ha with average revenue of $R p$ 21,159,420.00 / Ha of farmers earning income of Rp 17,147,182.00 / Ha. Analysis of return cost ratio get value > 1 so that pumpkin profitable for farmers and break even point analysis results showed that pumpkin farming is at break even point.
\end{abstract}

Keywords: Analysis, Farming, Yellow Pumpkin, Village Singsingon Raya, East Passi Subdistrict

\begin{abstract}
ABSTRAK
Penelitian ini bertujuan untuk menganalisis biaya dan pendapatan usahatani labu kuning di Desa Singsingon Raya Kecamatan Passi Timur. Penelitian dilaksanakan pada bulan Januari sampai Februari 2017. Data yang digunakan adalah data primer dan sekunder. Data primer melalui wawancara menggunakan kuisioner kepada 15 responden dan data sekunder diperoleh dari Kantor Desa Singsingon Raya. Analisis ini menggunakan analisis deskriptif. Hasil penelitian menunjukan bahwa biaya yang digunakan untuk berusahatani labu kuning paling besar adalah biaya tenaga kerja dan biaya transportasi sebesar $87,28 \%$. Dalam pemasaran labu petani memperoleh penerimaan yang cukup besar sehingga petani memperoleh pendapatan yang cukup besar. Hasilnya dapat dilihat dari total biaya produksi rata-rata sebesar Rp 4.012.238,00/Ha dengan penerimaan rata-rata sebesar $\mathrm{Rp} 21.159 .420,00 / \mathrm{Ha}$ petani memperoleh pendapatan sebesar $\mathrm{Rp}$ 17.147.182,00/Ha. Analisis return cost ratio memperoleh nilai >1sehingga berusahatani labu kuning menguntungkan bagi petani dan hasil analisis break even point menunjukan bahwa usahatani labu kuning berada pada titik impas.
\end{abstract}

Kata kunci: Analisis, Usahatani, Labu Kuning, Desa Singsingon Raya, Kecamatan Passi Timur 


\section{PENDAHULUAN}

\section{Latar Belakang}

Pembangunan ekonomi daerah merupakan suatu proses dimana pemerintah daerah dan masyarakat mengelola sumber daya yang ada dan membentuk suatu pola kemitraan antara pemerintah daerah dan sektor swasta untuk menciptakan suatu lapangan kerja baru dan merangsang perkembangan ekonomi dalam wilayah tersebut (Arsyad, 1999). Oleh karena itu, pembangunan daerah merupakan kegiatan yang berlandaskan pada kemampuan nasional dan berdasarkan perkembangan keadaan daerah (mencakup daerah kabupaten/kota, daerah provinsi dan masing-masing daerah otonom) dan nasional (Munji, 2001). Salah satu pengoptimalan sumber daya guna menunjang pembangunan wilayah perdesaan dapat dilakukan dengan mengidentifikasi komoditi-komoditi pertanian yang ada, sehingga pengembangannya dapat meningkatkan pertumbuhan dan pendapatan wilayah perdesaan. Dalam pengembangannya pemerintah perlu melihat sumber daya yang dimiliki disuatu desa, apabila sumber daya yang dimiliki melimpah maka perkembangan desanya akan cepat begitu pula sebaliknya apabila desa tersebut sumber dayanya sedikit maka perkembangan desanya akan lambat. Dalam melihat potensi yang ada perlu memperhatikan komoditas unggulan disetiap desa.

Pengembangan merupakan suatu usaha yang dilakukan untuk membuat produk semakin bermanfaat sehingga dapat meningkatkan kualitas sebagai upaya untuk menciptakan mutu yang lebih baik. Berdasarkan dari keanekaragaman kebudayaan dan sumber pangan, strategi pengembangan pangan di Indonesia perlu diarahkan pada potensi sumber daya wilayah (lokal). Salah satu sumber bahan pangan lokal yang ada di Indonesia adalah tanaman labu kuning. Labu kuning merupakan komoditi pertanian yang cocok untuk dikembangkan sebagai alternatif bahan pangan. Di Indonesia labu kuning banyak dimanfaatkan menjadi aneka produk makanan dan minuman seperti sirup, selai, kerupuk, bolu kering, sup, kolak dan dodol (Suprapti, 2005). Labu kuning yang selama ini ditanam pada lahan pertanian atau dilahan pekarangan, sebenarnya dapat dibudidayakan secara besar-besaran karena tanaman ini dapat menyesuaikan dengan keadaan alam yang berubah-ubah, saat hujan ataupun kemarau tanaman ini tetap hidup. Penduduk di Sulawesi Utara umumnya, memanfaatkan labu kuning sebagai makanan tradisional yang dikenal "bubur Manado". Manfaat labu kuning bagi penduduk yaitu pada anak-anak dapat digunakan sebagai penambah nafsu makan dan sebagai obat cacingan, kandungan vitamin $\mathrm{A}, \mathrm{B}$ dan $\mathrm{C}$, mineral serta karbohidrat dalam daging buah labu dapat digunakan sebagai antioksidan penangkal berbagai jenis kanker (Hidayah, 2010). Penduduk Manado menjadikan "bubur Manado" sebagai bahan komplementer nasi dan salah satu bahan bakunya adalah labu kuning. Di Manado banyak rumah makan yang menjual "bubur Manado" sebagai makanan sayuran, sehingga kebutuhan akan labu kuning sangat besar. Desa Singsingon Raya merupakan salah satu desa di Kecamatan Passi Timur Kabupaten Bolaang Mongondow yang memproduksi labu kuning. Usahatani labu kuning telah lama dibudidayakan pada desa tersebut, dimana petani sudah berpengalaman berusahatani dengan melihat kondisi tanah relatif cocok sehingga penanamannya tidak sulit baik dalam pembibitan, perawatan dan hasilnyapun cukup memberikan nilai ekonomis bagi masyarakat. Tanaman ini dapat ditanam dilahan pertanian, halaman pekarangan, baik didaerah tropis maupun sub tropis. Pada tahun 2015 produksi labu kuning di Desa Singsingon Raya berjumlah 34.000 buah dari hasil produksi terdapat ukuran labu kuning yang berbeda-beda ada yang berukuran kecil, sedang dan besar. Sebagai gambaran data produksi labu kuning Desa Singsingon Raya, dapat dilihat pada Tabel 1.

Tabel 1. Luas Lahan, Jumlah Petani dan Produksi Labu Kuning diDesa Sinmgsingon Raya

\begin{tabular}{lccc}
\hline Desa & $\begin{array}{c}\text { Luas } \\
\text { Lahan } \\
(\mathrm{Ha})\end{array}$ & $\begin{array}{c}\text { Produksi } \\
(\text { Buah })\end{array}$ & $\begin{array}{c}\text { Petani } \\
(\text { Org })\end{array}$ \\
\hline Singsingon & 1 & 1.000 & 2 \\
\hline $\begin{array}{l}\text { Singsingon } \\
\text { Barat }\end{array}$ & 31 & 31.000 & 25 \\
\hline $\begin{array}{l}\text { Singsingon } \\
\text { Timur }\end{array}$ & 2 & 2.000 & 4 \\
\hline
\end{tabular}

Sumber: Kantor Desa Singsingon Kecamatan Passi Timur, 2015. 
Produktivitas labu kuning di Desa Singsingon Raya akan diikuti dengan perubahan harga jual labu kuning dan akan mempengaruhi pendapatan yang akan diterima para petani labu kuning. Pada tahun 2016 jumlah petani yang berusahatani labu kuning di Desa Singsingon Raya sebanyak 15 petani. Hal ini menunjukan bahwa adanya penurunan jumlah petani labu kuning pada tahun 2015 dan 2016, dikarenakan umur panen labu kuning dan biaya yang dikeluarkan oleh para petani cenderung lebih besar dibandingkan pendapatan yang diperoleh para petani labu kuning.

\section{Rumusan Masalah}

Berdasarkan latar belakang yang telah dipaparkan, maka yang menjadi permasalahan adalah bagaimana biaya dan pendapatan usahatani labu kuning di Desa Singsingon Raya Kecamatan Passi Timur.

\section{Tujuan Penelitian}

Penelitian ini bertujuan untuk menganalisis biaya dan pendapatan usahatani labu kuning di Desa Singsingon Raya Kecamatan Passi Timur.

\section{Manfaat Penelitian}

Manfaat dari penulisan ini yaitu:

1) Bagi petani, dapat memberikan informasi dan bahan masukan tentang usahatani labu kuning.

2) Bagi pemerintah daerah, hasil penelitian ini diharapkan dapat menjadi sumbangan pemikiran dan bahan pertimbangan dalam pengembangan usahatani labu kuning.

3) Bagi penelitsi, sebagai tambahan pengetahuan dan wawasan tentang usahatani labu kuning di Desa Singsingon Raya Kecamatan Passi Timur.

\section{METODOLOGI PENELITIAN}

\section{Lokasi dan Waktu Penelitian}

Penelitian ini dilaksanakan di Desa Singsingon Kecamatan Passi Timur. Waktu penelitian selama dua bulan, mulai dari bulan Januari sampai bulan Februari 2017.

\section{Metode Pengambilan Sampel}

Pengambilan sampel secara sensus yaitu dengan menggunakan semua anggota populasi sebagai sampel dengan jumlah sampel sebanyak 15 petani labu kuning.

\section{Metode Pengumpulan Data}

Data yang digunakan dalam penelitian ini adalah data primer dan data sekunder. Data primer diperoleh melalui wawancara langsung dengan petani produsen menggunakan kuisioner sedangkan data sekunder merupakan data pendukung yang diperoleh dari kantor desa.

\section{Konsep Pengukuran Variabel}

1) Karakteristik responden:

a) Umur (tahun).

b) Tingkat pendidikan (SD, SMP, SMA, D1,S1).

c) Pekerjaan di luar usahatani labu kuning (buruh, wiraswasta, pedagang pengumpul dan tukang ojek).

d) Jumlah tanggungan anggota keluarga (orang).

e) Pengalaman berusahatani labu kuning (tahun).

2) Luas lahan, yaitu keseluruhan luas lahan yang digunakan dalam usahatani labu kuning (Ha).

3) Produksi, yaitu jumlah produksi labu kuning yang diperoleh dalam satu kali tanam (Rp/Buah).

4) Biaya produksi adalah semua pengeluaran yang dikeluarkan selama proses produksi yang terdiri dari biaya tetap dan biaya variabel (Rp).

a) Biaya tetap yaitu biaya yang umumnya selalu konstan seperti pajak.

b) Biaya variabel yaitu biaya yang umumnya berubah-ubah seperti: pupuk, pestisida, tenaga kerja dan biaya transportasi.

5) Pemasaran adalah kegiatan jual beli barang dan jasa seperti harga jual (Rp) dan tempat (pasar).

6) Penerimaan adalah perkalian antara produksi dengan harga jual (Rp/Buah).

7) Pendapatan usahatani adalah selisih antara penerimaan dan biaya $(\mathrm{Rp})$. 


\section{Metode Analisis Data}

Analisis data yang digunakan dalam penelitian ini adalah analisis deskriptif dan disajikan dalam bentuk tabel selanjutnya digunakan perhitungan analisis pendapatan. Untuk mengetahui tingkat keuntungan ekonomis labu kuning akan digunakan analisis return cost ratio dan break even point.

a) Pendapatan adalah selisih antara biaya dan penerimaan dengan rumus, yaitu:

$$
\mathbf{P}=\mathbf{T R}-\mathbf{T C}
$$

Keterangan : $\mathrm{P}=$ Pendapatan $\mathrm{TC}=$ Total Biaya $\mathrm{TR}=$ Total Penerimaan

b) Return Cost Ratio adalah perbandingan antara penerimaan dan biaya-biaya yang dikeluarkan selama proses produksi hingga menghasilkan produk. Dengan rumus :

$$
\mathbf{a}=\mathbf{R} / \mathbf{C}
$$

Keterangan : $\mathrm{A}=$ Return Cost Ratio

$$
\begin{aligned}
& \mathrm{R}=\text { Penerimaan } \\
& \mathrm{C}=\text { Biaya }
\end{aligned}
$$

Secara teoritis dengan ratio $\mathrm{R} / \mathrm{C}$ :

$>1$ artinya usahatani tersebut menggalami keuntungan.

$\neq 1$ artinya usahatani tidak untung dan tidak rugi.

$<1$ artinya usahatani menggalami kerugian.

c) Break Even Point adalah sebuah titik dimana biaya dan pendapatan adalah seimbang sehingga tidak terdapat kerugian atau keuntungan.

Perhitungan BEP :

1) $\mathrm{BEP}$ Produksi $=\frac{\mathrm{FC}}{\mathrm{P}-\mathrm{VC}}$

$$
\begin{aligned}
\text { Keterangan : FC }: \text { Biaya Tetap } \\
\text { P : Harga Jual Per Unit } \\
\text { VC : Biaya Variabel Per Unit }
\end{aligned}
$$

2) BEP Harga $=\frac{F C}{1-V C / P}$

Keterangan: FC : Biaya Tetap

VC : Biaya Variabel Per Unit

P : Harga Jual Per Unit

\section{HASIL DAN PEMBAHASAN}

\section{Deskripsi Lokasi Penelitian}

\section{Keadaan Geografis Lokasi Penelitian}

Singsingon Raya merupakan salah satu desa yang ada di Kecamatan Passi Timur Kabupaten Bolaang-Mongondow. Provinsi
Sulawesi Utara. Luas wilayah Desa Singsingon Raya $28,5 \mathrm{Km}^{2}$ dan berpenduduk sebanyak 2.089 jiwa, terdiri dari 1.100 jiwa laki-laki dan 987 jiwa perempuan. Jarak dengan ibukota kabupaten/kota $67 \mathrm{Km}$. Desa Singsingon Raya berada pada ketinggian 1.085 Mdpl (meter diatas permukaan laut), dengan suhu udara 24$26^{\circ} \mathrm{C}$. Batas wilayah administratif Desa Singsingon Raya sebagai berikut :
a) Sebelah Utara
: Hutan Lindung
b) Sebelah Timur
: Desa Insil
c) Sebelah Selatan
: Hutan Lindung
d) Sebelah Barat
: Perkebunan Pogat

\section{Umur}

\section{Karakteristik Responden}

Umur merupakan faktor penting dalam berproduksi usahatani labu kuning. Umur mempengaruhi kemampuan seseorang untuk bekerja secara fisik dan menentukan cara berpikir. Untuk umur produktif pada usia 16 tahun sampai 60 tahun. Umur produktif adalah penduduk yang karena usianya dapat menghasilkan produk maupun jasa. Umur responden dapat dilihat pada Tabel 2 .

Tabel 2. Umur Responden Petani Labu Kuning

\begin{tabular}{cccc}
\hline \multirow{2}{*}{ No } & \multirow{2}{*}{$\begin{array}{c}\text { Umur } \\
\text { (Tahun) }\end{array}$} & Jumlah Responden (Orang ) \\
\cline { 3 - 4 } & $<30$ & 2 & Persentase \\
\hline 1 & $30-60$ & 12 & 13,33 \\
2 & $30-60,00$ \\
3 & $>60$ & 1 & 6,67 \\
\hline \multicolumn{2}{c}{ Jumlah } & $\mathbf{1 5}$ & $\mathbf{1 0 0}$ \\
\hline \multicolumn{2}{l}{ Sumber : Diolah dari data primer, 2017 }
\end{tabular}

Sumber : Diolah dari data primer, 2017

Pada Tabel 2 menunjukan umur responden sebagian besar berada pada umur 30 sampai 60 tahun sebanyak 12 responden dengan persentase $80,00 \%$. Jumlah ini menunjukan bahwa sebagian besar petani labu kuning berada pada usia produktif, dimana petani cukup potensial untuk melakukan kegiatan usahataninya.

\section{Tingkat Pendidikan}

Tingkat pendidikan yang dimiliki oleh seorang petani akan berpengaruh pada kemampuannya untuk mengelola usahatani serta menerapkan pada pengembangan usahataninya. Berdasarkan penelitian, tingkat pendidikan petani dapat dilihat pada Tabel 3 . 
Tabel 3. Tingkat Pendidikan Petani

\begin{tabular}{cccc}
\hline No & $\begin{array}{c}\text { Tingkat } \\
\text { Pendidikan }\end{array}$ & $\begin{array}{c}\text { Jumlah Responden (Orang) } \\
\text { Jumlah }\end{array}$ & \begin{tabular}{c} 
Persentase \\
\hline 1
\end{tabular} \\
SD & 3 & 20,00 \\
2 & SMP & 7 & 46,67 \\
3 & SMA & 4 & 26,67 \\
4 & D1 & 1 & 6,67 \\
\hline & Jumlah & $\mathbf{1 5}$ & $\mathbf{1 0 0}$ \\
\hline
\end{tabular}

Sumber : Diolah dari data primer, 2017

Tabel 3 menunjukan tingkat pendidikan petani sampel di daerah penelitian sebagian besar berada pada tingkat SMP (Sekolah Menengah pertama) yaitu dengan persentase 46,67 \%, SMA (Sekolah Menengah Atas) dengan persentase 26,67 \%, SD (Sekolah Dasar) dengan persentase $20,00 \%$ dan D1 dengan persentase $6,67 \%$.

\section{Pekerjaan di Luar Usahatani Labu Kuning}

Untuk mencukupi kebutuhan keluarga para petani memiliki pekerjaan sampingan atau pekerjaan diluar usahatani labu kuning. Pekerjaan petani meliputi buruh, pedagang pengumpul, tukang ojek dan wiraswasta. Pekerjaan sampingan petani dapat dilihat pada Tabel 4.

Tabel 4. Pekerjaan di Luar Usahatani Labu

\begin{tabular}{clcc}
\multicolumn{2}{c}{ Kuning } & \multicolumn{2}{c}{$\begin{array}{c}\text { Jumlah Responden } \\
\text { (Orang) }\end{array}$} \\
\hline \multirow{2}{*}{ No } & $\begin{array}{c}\text { Pekerjaan di Luar } \\
\text { Usahatani Labu } \\
\text { Kuning }\end{array}$ & \multicolumn{2}{c}{$\begin{array}{c}\text { Jumlah } \\
\text { Persentase }\end{array}$} \\
\cline { 3 - 4 } 1 & Buruh Tani & 10 & 66,67 \\
& Pedagang & & \\
& Pengumpul Bawang & & 13,33 \\
2 & dan Kentang & 2 & 6,67 \\
3 & Tukang Ojek & 1 & 13,33 \\
4 & Wiraswasta & 2 & $\mathbf{1 0 0}$ \\
\hline & $\quad$ Jumlah & $\mathbf{1 5}$ &
\end{tabular}

Sumber : Diolah dari data primer, 2017

Pada Tabel 4 menunjukan pekerjaan petani di luar usahatani labu kuning sebagian besar bekerja sebagai buruh tani dengan persentase $66,67 \%$, pedagang pengumpul dengan persentase $13,33 \%$, wiraswasta dengan persentase $13,33 \%$ dan bekerja sebagai tukang ojek dengan persentase $6,67 \%$.

\section{Jumlah Tanggungan Anggota Keluarga}

Jumlah tanggungan anggota keluarga adalah keseluruhan anggota keluarga yang jumlah kebutuhan atau biaya anggota keluarga ditanggung oleh kepala keluarga. Anggota keluarga yang terhitung dalam jumlah tanggungan umumnya membantu keluarga dalam hal penyediaan tenaga kerja khususnya dalam bidang pertanian. Ketersediaan tenaga kerja dalam keluarga dengan sendirinya akan mengurangi masuknya tenaga kerja dari luar keluarga. Dari hasil penelitian jumlah tanggungan anggota keluarga dapat dilihat pada Tabel 5.

Tabel 5. Jumlah Tanggungan Anggota Keluarga

\begin{tabular}{cccc}
\hline \multirow{2}{*}{ No } & $\begin{array}{c}\text { Anggota } \\
\text { Keluarga }\end{array}$ & \multicolumn{2}{c}{ Jumlah Responden (Orang ) } \\
\cline { 3 - 4 } & $1-2$ & Jumlah & Persentase \\
\hline 1 & $3-4$ & 6 & 40,00 \\
2 & $\geq 5$ & 1 & 53,33 \\
3 & Jumlah & $\mathbf{1 5}$ & 6,67 \\
\hline &
\end{tabular}

Sumber : Diolah dari data primer, 2017

Tabel 5 menunjukan jumlah tanggungan anggota keluarga terbanyak terdapat pada jumlah tanggungan anggota keluarga yaitu 3 sampai 4 dengan persentase $53,33 \%$. Jumlah ini menunjukan bahwa tanggungan anggota keluarga dapat membantu dalam proses usahatani labu kuning terutama dalam penyediaan tenaga kerja keluarga. Anggota keluarga di Desa Singsingon Raya sudah terlibat dalam aktifitas usahatani.

\section{Pengalaman Berusahatani Labu Kuning}

Pengalaman berusahatani merupakan salah satu faktor penentu keberhasilan usahatani. Petani yang sudah berpengalaman dalam usahatani cenderung lebih terampil dalam mengelola usahataninya. Berdasarkan pengalaman tersebut, petani dapat meningkatkan produksi labu kuning melalui komunikasi antar petani. Pengalaman berusahatani labu kuning dapat dilihat pada Tabel 6.

Tabel 6. Pengalaman Berusahatani Labu Kuning

\begin{tabular}{cccc}
\hline \multirow{2}{*}{ No } & \multirow{2}{*}{$\begin{array}{c}\text { Pengalaman } \\
\text { (Tahun) }\end{array}$} & \multicolumn{2}{c}{$\begin{array}{c}\text { Jumlah Responden } \\
\text { (Orang) }\end{array}$} \\
\cline { 3 - 4 } & $0-5$ & Jumlah & Persentase \\
\hline 1 & $6-10$ & 6 & 33,33 \\
2 & $11-15$ & 4 & 40,00 \\
3 & Jumlah & $\mathbf{1 5}$ & $\mathbf{1 0 0}$ \\
\hline
\end{tabular}

Sumber : Diolah dari data primer, 2017

Tabel 6 menunjukan bahwa pengalaman petani bekerja sebagai petani labu kuning 6 sampai 10 tahun sebanyak 6 responden dengan 
persentase 40,00\%, 0 sampai 5 tahun sebanyak 5 responden dengan persentase 33,33\%, 11 sampai 15 tahun sebanyak 4 responden dengan persentase 26,67 \%. Tingkat pengalaman berusahatani labu kuning bagi sebagian besar petani sudah cukup berpengalaman sehingga dalam menjalankan aktivitasnya sebagai petani labu kuning cukup baik dan tanaman labu kuning sudah cukup produktif. Dalam halnya bertani, petani mengenal tanaman labu kuning sudah lama dan teknik budidaya labu kuning sudah turun-temurun.

\section{Usahatani Labu Kuning di Desa Singsingon Lahan}

Lahan merupakan salah satu faktor penting dalam berusahatani. Lahan juga merupakan salah satu faktor yang mempengaruhi pendapatan yang akan diterima oleh petani dalam berusahatani labu kuning. Dengan adanya lahan pertanian untuk berusahatani labu kuning maka petani akan berusaha untuk meningkatkan produksi sehingga pendapatan yang akan diterima petani juga meningkat dan petani dapat mengusahakan berbagai komoditi yang sesuai dengan jenis tanah yang akan ditanami. Hasil penelitian menunjukan, luas lahan tanaman hortikultura di Desa Singsingon Raya berjumlah 928 Ha dan luas lahan yang digunakan untuk berusahatani labu kuning berjumlah 10,4 Ha. Luas lahan pertanian yang belum diusahakan berjumlah 30 Ha. Jumlah ini menunjukan bahwa, petani mempunyai peluang untuk meningkatkan produksi labu kuning dengan mengusahakan lahan pertanian yang belum diusahakan. Luas lahan yang dimiliki petani akan mempengaruhi produksi usahatani labu kuning. Luas lahan juga merupakan faktor produksi terpenting dalam kegiatan usahatani, karna lahan merupakan tempat untuk menanam komoditi yang akan dibudidayakan oleh petani. Luas lahan dapat dilihat pada Tabel 7.

Tabel 7. Luas Lahan Petani Labu Kuning

\begin{tabular}{cccc}
\hline \multirow{2}{*}{ No } & \multirow{2}{*}{$\begin{array}{c}\text { Luas Lahan } \\
\text { (Ha) }\end{array}$} & \multicolumn{2}{c}{$\begin{array}{c}\text { Jumlah Responden } \\
\text { (Orang) }\end{array}$} \\
\cline { 3 - 4 } & & Jumlah & Persentase \\
\hline 1 & $<0,5$ & 2 & 13,33 \\
2 & $0,5-1$ & 13 & 86,67 \\
\hline & Jumlah & $\mathbf{1 5}$ & $\mathbf{1 0 0}$ \\
\hline
\end{tabular}

Sumber : Diolah dari data primer, 2017.
Tabel 7 menunjukan luas lahan petani yang digunakan pada usahatani labu kuning terbanyak pada 0,5 sampai 1 Ha dengan persentase 86,67\% sedangkan kurang dari 0,5 $\mathrm{Ha}$ dengan persentase $13,33 \%$.

\section{Status Kepemilikan Lahan}

Status kepemilikan lahan sangat berpengaruh terhadap tingkat pendapatan petani karena status kepemilikan lahan juga mempengaruhi biaya yang akan dikeluarkan oleh petani. Kepemilikan lahan dapat dilihat pada Tabel 8.

Tabel 8. Status Kepemilikan Lahan

\begin{tabular}{cccc}
\hline \multirow{2}{*}{ No } & \multirow{2}{*}{ Status Lahan } & \multicolumn{2}{c}{$\begin{array}{c}\text { Jumlah Responden } \\
\text { (Orang ) }\end{array}$} \\
\cline { 3 - 4 } & & Jumlah & Persentase \\
\hline 1 & Milik Sendiri & 12 & 80,00 \\
2 & Pinjam & 3 & 20,00 \\
\hline & Jumlah & $\mathbf{1 5}$ & $\mathbf{1 0 0}$ \\
\hline
\end{tabular}

Sumber : Diolah dari data primer, 2017.

Pada Tabel 8 menunjukan kepemilikan lahan petani labu kuning sebagian besar adalah milik sendiri dengan persentase 80,00 \% sedangkan kepemilkan lahan berstatus pinjam dengan persentase $20,00 \%$. Para petani responden menggarap lahannya dengan membudidayakan berbagai macam jenis tanaman seperti bawang daun, kentang, wortel, tomat dan labu kuning.

\section{Bibit}

Pembibitan merupakan hal penting yang dilakukan untuk mendapatkan produksi labu kuning yang baik. Salah satu tahapan peningkatan produksi labu kuning adalah pemilihan bibit yang baik. Bibit yang baik adalah bibit yang tidak rusak, layu dan busuk. Hasil penelitian menunjukan bahwa petani dalam usahataninya membuat bibit labu kuning sendiri dan tidak membeli bibit labu kuning. Benih yang digunakan merupakan benih hasil produksi sendiri. Hal ini dilakukan untuk menghemat biaya produksi. Proses pembuatan bibit labu kuning adalah dengan cara mengambil buah yang matang dan yang bagus, setelah itu biji/benih yang ada pada buah labu dibersihkan dan dijemur. Setelah biji/benih buah labu kuning menggering, langsung bisa dijadikan bibit. Pembuatan bibit labu kuning dalam $1 \mathrm{Ha}$ diperlukan 5 sampai 10 buah labu kuning. 


\section{Teknik Budidaya Usahatani Labu Kuning}

Usahatani labu kuning merupakan usahatani yang tidak sulit dibudidayakan baik dalam pembibitan dan perawatan. Penanaman labu kuning di Desa Singsingon dilakukan dengan monokultur, dikarenakan ketika ditanam secara tumpang sari tanaman labu kuning akan merabat pada tanaman lainnya. Kegiatan usahatani labu kuning dimulai dari pengolahan lahan, penanaman, pemeliharaan, penyiangan dan pemanenan. Kegiatan pengolahan lahan bertujuan untuk membersihkan lahan dari rumput-rumput liar (gulma) dan untuk menggemburkan tanah kemudian membuat bedengan dan juga memberikan pupuk kandang. Petani di Desa Singsingon melakukan penanaman secara langsung dengan cara membuat lubang dan menaruh benih labu kuning sebanyak 3 sampai 5 benih. Pola tanam yang digunakan petani labu kuning antara tanaman satu dengan yang lainnya adalah 3 sampai 4 meter. Pemeliharaan tanaman pada saat tanaman berumur 3 minggu meliputi kegiatan penyulaman yaitu mengganti benih labu kuning yang mati dengan benih yang baru selanjutnya, kegiatan pengairan dilakukan pada saat tanaman berumur 4 minggu dan 6 minggu yang ditentukan oleh keadaan tanah dan cuaca kemudian, pemupukan yang dilakukan dua kali yaitu ketika tanaman berumur 4 minggu dan 8 minggu. Hal tersebut dilakukan petani sebagai usaha untuk memaksimalkan produksi yang akan dihasilkan selanjutnya, perlindungan tanaman dengan penyemprotan unsur kimiawi (pestisida) sesuai dengan jenis dan dosis yang dianjurkan. Penggunaan obat-obatan oleh para petani responden beragam atau bermacammacam jenis seperti Korakron, Seprin, Bayfolan, Grenflora, fastac, Petrovita. Bagi petani di Desa Singsingon seranggan hama dan penyakit tanaman labu kuning dapat menurunkan hasil produksi dan akan menimbulkan kerugian pada petani. Kegiatan selanjutnya adalah penyiangan yaitu untuk membersihkan tanaman dari rumput-rumput liar (gulma) yang dilakukan ketika tanaman berumur 3 minggu dan 6 minggu.

Pemanenan adalah saat yang dinantikan oleh petani sebagai perwujudan dari keberhasilan dalam mengusahakan tanaman labu kuning. Labu kuning dipanen pada umur tanaman 4 sampai 5 bulan. Proses panen labu kuning secara bertahap dengan melihat buah yang sudah matang. Pemanenan buah labu kuning dilakukan dengan memangkas atau memotong tangkai buah. Pemanenan buah labu kuning sampai tujuh kali panen dalam satu kali tanam dengan selang waktu pemanenan adalah 2 sampai 3 minggu. Tanaman labu kuning layu pada umur tanaman 6 bulan setelah buah labu dipanen tanaman langsung mati. Dalam luasan lahan $0,5 \mathrm{Ha}$ dengan jarak tanam 3 meter terdapat 23 bedeng tanaman labu kuning dan disetiap bedeng terdapat 11 pohon labu kuning dan dalam 1 pohon terdapat 4 sampai 7 buah labu kuning. Pada tanaman labu kuning yang tidak rusak dan subur, produksi labu kuning pada luasan lahan 0,5 Ha berkisar 1.000 buah. Dari hasil penelitian rata-rata produksi labu kuning yang dihasilkan petani selama 4 sampai 5 bulan di Desa Singsingon mencapai 1.662 buah/Ha.

Kebutuhan tenaga kerja untuk usahatani labu kuning di lokasi penelitian sangat mudah dipenuhi. Tenaga kerja untuk bidang pertanian dapat berupa tenaga kerja dalam keluarga yaitu tenaga kerja yang berasal dari anggota keluarga petani dan tenaga kerja luar keluarga yaitu tenaga kerja yang merupakan tenaga upahan. Jam atau waktu kerja yang diberlakukan di Desa Singsingon Raya adalah mulai pukul 07:00 sampai pukul 16:00. Tenaga kerja dalam usahatani labu kuning di Desa Singsingon Raya menggunakan tenaga kerja laki-laki. Tingkat upah rata-rata yang dibayarkan untuk tenaga kerja laki-laki mulai dari pengolahan lahan sampai panen adalah $\mathrm{Rp} 1.848 .792,00 / \mathrm{Ha}$. Jumlah tenaga kerja yang digunakan untuk pengolahan lahan sebanyak 117 orang, penanaman sebanyak 49 orang, pemeliharaan tanaman sebanyak 27 orang, pemupukan sebanyak 21 orang, penyiangan sebanyak 88 orang dan pemanenan sebanyak 55 orang. Jumlah anggota keluarga yang terlibat dalam usahatani labu kuning ratarata sebanyak 3 sampai 4 orang terdiri dari istri dan anak-anak petani. Hasil penelitian menunjukan bahwa petani labu kuning yang ada di Desa Singsingon Raya dalam usahataninya menggunakan teknik budidaya yang tradisional. 
Dari pengalaman berusahatani, teknik budidaya tradisional lebih memudahkan petani dalam berusahatani dan lebih menguntungkan.

\section{Hambatan Usahatani Labu Kuning}

Dalam proses berusahatani, petani labu kuning tidak mempunyai masalah atau kendala dalam hal budidaya, dikarenakan petani sudah terbiasa berusahatani labu kuning dan tanaman labu kuning tidak membutuhkan banyak perawatan serta tidak membutuhkan banyak biaya. Dalam halnya pemasaran petani tidak ada kendala dalam menjual buah labu kuning, dikarenakan pedagang-pedagang pengumpul yang datang sendiri dirumah petani dan ada petani yang sudah mempunyai pelangan tetap atau pedagang pengumpul tetap sehingga dalam proses pemasaran petani tidak mempunyai kendala. Petani mempunyai kendala atau masalah ketika adanya hama yang ada pada tanaman labu kuning yang mengakibatkan buah labu kuning membusuk dan rusak sehingga hasil produksi menjadi sedikit dan petani menggalami kerugian.

\section{Produksi}

Produksi merupakan suatu kegiatan atau proses yang mengubah faktor-faktor produksi menjadi suatu produk. Volume produksi labu kuning dapat dilihat pada Tabel 9.

Tabel 9. Volume Produksi Labu Kuning

\begin{tabular}{cccc}
\hline \multirow{2}{*}{ No } & $\begin{array}{c}\text { Jumlah } \\
\text { Produksi } \\
\text { (Buah) }\end{array}$ & \multicolumn{2}{c}{$\begin{array}{c}\text { Jumlah Responden } \\
\text { (Orang) }\end{array}$} \\
\cline { 3 - 4 } & $750-1.000$ & Jumlah & Persentase \\
\hline 1 & $1.001-1.500$ & 6 & 60,00 \\
2 & Jumlah & $\mathbf{1 5}$ & $\mathbf{1 0 0}$ \\
\hline
\end{tabular}

Sumber : Diolah dari data primer, 2017.

Tabel 9 menunjukan bahwa produksi labu kuning yang dihasilkan oleh petani dalam satu kali tanam terbanyak pada jumlah produksi 750 sampai 1.000 buah dengan persentase 60,00 $\%$. Banyaknya produksi labu kuning yang dihasilkan oleh petani bervariasi. Rata-rata produksi labu kuning yang dihasilkan oleh setiap petani di Desa Singsingon adalah 1.147 buah dan Per Ha adalah 1.662 buah. Volume produksi merupakan faktor penentu besarnya pendapatan yang diterima oleh petani labu kuning. Semakin besar volume produksi yang dihasilkan, maka akan semakin tinggi pulah pendapatan para petani labu kuning di Desa Singsingon Raya.

\section{Biaya Produksi}

Biaya produksi adalah semua biaya yang dikeluarkan petani untuk memproduksi barang/jasa. Biaya produksi dalam hal ini menyangkut semua pengeluaran yang dikeluarkan dari pengolahan lahan sampai panen. Biaya produksi pada tanaman labu kuning terbagi atas dua macam yaitu biaya tetap dan biaya variabel. Biaya tetap adalah biaya yang terus dikeluarkan walaupun produksi yang dikeluarkan sedikit ataupun banyak sedangkan biaya variabel adalah biaya yang besar kecilnya dipengaruhi oleh produksi yang diperoleh.

\section{Biaya Tetap}

Biaya tetap adalah biaya yang harus dikeluarkan petani dalam berusahatani labu kuning yang sifatnya tetap dan tidak berubah. Biaya tetap yang dikeluarkan petani dalam berusahatani labu kuning yaitu biaya pajak. Biaya pajak dapat dilihat pada Tabel 10.

Tabel 10. Biaya Pajak Labu Kuning

\begin{tabular}{cccc}
\hline \multirow{2}{*}{ No } & $\begin{array}{c}\text { Besarnya } \\
\text { Pajak (Rp) }\end{array}$ & \multicolumn{2}{c}{$\begin{array}{c}\text { Jumlah Responden } \\
\text { (Orang) }\end{array}$} \\
\cline { 3 - 4 } & & Jumlah & Persentase \\
\hline 1 & $1.000-5.000$ & 2 & 13,33 \\
2 & $6.000-10.000$ & 9 & 60,00 \\
3 & $11.000-15.000$ & 1 & 6,67 \\
4 & $16.000-20.000$ & 3 & 20,00 \\
\hline Jumlah & $\mathbf{1 5}$ & $\mathbf{1 0 0}$ \\
\hline \multicolumn{2}{c}{ Rata-rata } \\
\hline
\end{tabular}

Sumber : Diolah dari data primer, 2017

Tabel 10 menunjukan biaya pajak terbanyak yang dikeluarkan dalam berusahatani labu kuning adalah sebesar Rp 6.000,00 sampai Rp 10.000,00 dengan persentase 60,00 \% sebanyak 9 responden sedangkan biaya pajak paling sedikit yang dikeluarkan adalah sebesar Rp 11.000,00 sampai Rp 15.000,00 dengan persentase 6,67 \% sebanyak 1 responden. Ratarata besarnya pajak yang dikeluarkan oleh petani labu kuning di Desa Singsingon Raya sebesar Rp. 14.412,00/Ha. 


\section{Biaya Variabel}

Biaya variabel yang dikeluarkan petani dalam berusahatani labu kuning yaitu biaya pupuk, pestisida, tenaga kerja dan biaya transportasi. Dalam penelitian yang sudah dilakukan, rata-rata keseluruhan biaya variabel dapat dilihat pada Tabel 11.

Tabel 11. Rata-rata Biaya Variabel Per Ha

\begin{tabular}{|c|c|c|c|}
\hline No & $\begin{array}{c}\text { Biaya } \\
\text { Keseluruhan }\end{array}$ & Jumlah (Rp) & Persentase \\
\hline 1 & Pupuk & 428.726 & 10,66 \\
\hline 2 & Pestisida & 82.850 & 2,06 \\
\hline 3 & Tenaga kerja & 1.848 .792 & 45,96 \\
\hline 4 & Transportasi & 1.661 .836 & 41,32 \\
\hline Tot & & 4.022 .204 & 100 \\
\hline
\end{tabular}

Sumber : Diolah dari data primer lampiran, 2017.

Pada Tabel 11 menunjukan rata-rata biaya variabel responden yang paling besar dikeluarkan adalah biaya tenaga kerja sebesar Rp 1.848.792,00/Ha dengan persentase 45,96 $\%$ sedangkan biaya yang paling rendah adalah biaya pestisida sebesar $\mathrm{Rp} 82.850,00 / \mathrm{Ha}$ dengan persentase 2,06 \%. Biaya pupuk sebesar $\mathrm{Rp}$ 428.726,00 terdiri dari biaya pupuk SP dan pupuk Ponska. Biaya pestisida sebesar Rp 82.850,00 terdiri dari biaya Korakron, Seprin, Bayfolan, Grenflora, fastac, Petrovita. Biaya tenaga kerja sebesar Rp 1.848.792,00 sudah termasuk biaya tenaga kerja diluar anggota keluarga mulai dari pengolahan lahan sampai pemanenan. Biaya transportasi sebesar Rp 1.661.836,00 digunakan untuk mengangkut produksi labu kuning terdiri dari biaya mobil dan motor.

\section{Pemasaran Hasil Produksi}

Pemasaran adalah suatu kegiatan bisnis yang ditunjukan untuk merencanakan, menentukan harga, mempromosikan dan mendistribusikan barang atau jasa kepada konsumen. Hasil penelitian menunjukan petani menjual labu kuning pada pedagang pengumpul, dijual langsung kepada pedagang dan ada juga buah labu kuning yang diolah menjadi produk makanan seperti olahan sayur dan bubur Manado. Harga jual labu kuning ditentukan oleh pedagang pengumpul. Harga jual labu kuning juga bervariasi berdasarkan ukuran dan jarak pemasaran. Hasil penelitian menunjukan bahwa pedagang pengumpul di Kotamobagu memasarkan labu kuning di Gorontalo dan Dumoga, pedagang pengumpul di Modoinding memasarkan labu kuning di Manado dan Kotamobagu, pedagang pengumpul di Manado memasarkan labu kuning di Manado dan Bitung, pedagang pengumpul di Langowan memasarkan labu kuning di Langowan dan Manado. Pada saat penelitian rata-rata harga jual labu kuning sebesar $\mathrm{Rp}$ $17.585,00 / \mathrm{Ha}$ dengan kesaran harga $\mathrm{Rp}$ 5.000,00 sampai Rp 20.000,00/buah. Labu kuning yang jarak pemasarannya berjauhan antara tempat produksi dengan pasar dan berukuran kecil berjumlah Rp 5.000,00 sampai Rp 6.000,00 dan labu kuning yang jarak pemasaran berjauhan antara tempat produksi dengan pasar dan berukuran sedang berjumlah Rp 10.000,00 sampai Rp 15.000,00 serta labu kuning yang jarak pemasarannya berjauhan antara tempat produksi dengan pasar dan berukuran besar $\mathrm{Rp} 15.000,00$ sampai $\mathrm{Rp}$ $20.000,00$. Pemasaran hasil produksi menurut harga jual dan ukuran buah labu kuning serta daerah pemasarannya dapat dilihat pada Tabel 12.

Tabel 12. Pemasaran Hasil Produksi Buah Labu Kuning Berdasarka Harga Jual dan Ukuran serta Daerah Pemasaran

\begin{tabular}{ccccc}
\hline & $\begin{array}{c}\text { Daerah } \\
\text { Pemasaran } \\
\text { No }\end{array}$ & \multicolumn{3}{c}{$\begin{array}{c}\text { Harga Labu Kuning Sesuai } \\
\text { Ukuran (Rp/ Buah) }\end{array}$} \\
\cline { 3 - 5 } & $\begin{array}{c}\text { Pedagang } \\
\text { Pengumpul) }\end{array}$ & Kecil & Sedang & Besar \\
\hline 1 & Kotamobagu & $5.000,00$ & $10.000,00$ & $15.000,00$ \\
2 & Modoinding & $5.000,00$ & $10.000,00$ & $20.000,00$ \\
3 & Manado & $6.000,00$ & $15.000,00$ & $20.000,00$ \\
4 & Langowan & $6.000,00$ & $15.000,00$ & $20.000,00$ \\
\hline Sumber : Diolah dari data primer, 2017.
\end{tabular}

Tabel 12 menunjukan bahwa harga jual labu kuning bervariasi untuk setiap daerah pemasaran. Perbedaan harga ditetapkan berdasarkan pada lokasi dan ukuran labu kuning. Pada setiap daerah pemasaran di Manado dan Langowan harga jual labu kuning untuk setiap ukuran baik kecil, sedang maupun besar lebih mahal dari daerah Kotamobagu dan Modoinding. Hal tersebut dikarenakan jarak tempuh pemasaran dari Singsingon ke daerah Manado dan Langowan lebih jauh dari 
Kotamobagu dan Modoinding. Jarak merupakan penambahan biaya ketika tempat produksi barang/jasa berjauhan dengan pasar dan ukuran labu kuning berpengaruh pada saat pedagang pengumpul melakukan pemisahan antara buah labu kuning yang baik dan busuk.

\section{Penerimaan Usahatani Labu Kuning}

Penerimaan usahatani labu kuning adalah perkalian antara jumlah produksi labu kuning dan harga. Oleh karena itu besarnya penerimaan usahatani labu kuning tergantung pada jumlah produksi dan harga. Hasil penelitian menunjukan bahwa rata-rata penerimaan oleh petani labu kuning di Desa Singsingon Raya sebesar Rp 21.159.420,00/Ha.

\section{Pendapatan Usahatani Labu Kuning}

Pendapatan merupakan hasil dari suatu usaha yang akan dinilai dari biaya yang dikeluarkan dan penerimaan yang diperoleh. Pendapatan adalah selisih penerimaan dan biaya dalam suatu proses produksi. Secara umum tujuan usahatani labu kuning adalah untuk memperoleh pendapatan yang besar sehingga dalam berusahatani labu kuning petani diuntungkan dan tidak rugi. Dalam penelitan yang sudah dilakukan, rata-rata pendapatan per Ha petani dalam satu kali tanam dapat dilihat pada Tabel 13.

Tabel 13. Rata-rata Pendapatan Petani per Ha

\begin{tabular}{lc}
\hline Uraian & Total $(\mathbf{R p} / \mathbf{H a})$ \\
\hline Biaya & $4.012 .238,00$ \\
Penerimaan & $21.159 .420,00$ \\
\hline Pendapatan & $\mathbf{1 7 . 1 4 7 . 1 8 2 , 0 0}$ \\
\hline Sumber $:$ Diolah dari data primer lampiran, 2017
\end{tabular}

Tabel 13 menunjukan rata-rata pendapatan petani dalam satu kali tanam dengan tujuh kali panen sebesar Rp 17.147.182,00/Ha.

\section{Hasil Analisis}

\section{Pendapatan}

Pendapatan adalah selisih antara biaya yang dikeluarkan dalam berusahatani labu kuning dan penerimaan yang diperoleh petani dalam berusahatani labu kuning.

$$
\begin{aligned}
\mathrm{P} & =\mathrm{TR}-\mathrm{TC} \\
& =21.159 .420-4.012 .238 \\
& =17.147 .182
\end{aligned}
$$

Hasil perhitungan dengan menggunakan rumus pendapatan memperoleh nilai sebesar 17.147.182. Nilai ini dapat memberikan arti bahwa dalam berusahatani labu kuning petani dapat memperoleh keuntungan sebesar Rp 17.147.182,00.

\section{Return Cost Ratio}

Untuk mengetahui tingkat keuntungan ekonomis usahatani labu kuning di Desa Singsingon dapat diketahui dengan menggunakan analisis return cost ratio. Analisis R/C adalah perbandingan antara penerimaan dan biaya.

$$
\begin{aligned}
\mathrm{a} & =\mathrm{R} / \mathrm{C} \\
& =21.159 .420 / 4.012 .238 \\
& =5
\end{aligned}
$$

Hasil perhitungan dengan menggunakan rumus return cost ratio memperoleh nilai sebesar 5. Nilai ini dapat memberikan arti bahwa usahatani labu kuning di Desa Singsingon Raya Kecamatan Passi Timur dalam satu kali tanam dengan tujuh kali panen terlihat menguntungkan.

\section{Break Even Point}

Break Even Point adalah sebuah titik dimana biaya atau pengeluaran dan pendapatan adalah seimbang sehingga tidak terdapat kerugian atau keuntungan atau untuk mengetahui keadaan impas (kembali modal) yang diperoleh dari usahatani tersebut diketahui dengan menghitung BEP Harga dan Produksi sebagai berikut

$$
\begin{aligned}
\text { - } \quad \text { BEP Produksi } & =\frac{\mathrm{FC}}{\mathrm{P}-\mathrm{VC}} \\
& =\frac{9.945}{12.133-2.738 .610} \\
& =274,15 \text { buah } \\
\text { BEP Harga }= & \frac{\mathrm{FC}}{1-\mathrm{VC} / \mathrm{P}} \\
= & \frac{9.945}{1-2.738 .610 / 12.133} \\
& =\operatorname{Rp} 274,15
\end{aligned}
$$

Hasil perhitungan dengan menggunakan rumus break even point menunjukan bahwa pada saat produksi 274,15 buah dan harga $\mathrm{Rp}$ 274,15,00/buah menyatakan bahwa usahatani labu kuning di Desa Singsingon Raya, berada pada titik impas (Break Even Point). 


\section{KESIMPULAN DAN SARAN}

\section{Kesimpulan}

Berdasarkan hasil penelitian mengenai Analisis Usahatani Labu Kuning di Desa Singsingon Raya Kecamatan Passi Timur, maka dapat disimpulkan bahwa biaya yang digunakan untuk berusahatani labu kuning paling besar adalah biaya tenaga kerja dan biaya transportasi sebesar 87,28 \%. Dalam pemasaran labu kuning petani memperoleh penerimaan yang cukup besar sehingga petani memperoleh pendapatan yang cukup besar. Hasilnya dilihat dari total biaya produksi rata-rata sebesar $\mathrm{Rp}$ 4.012.238,00/Ha dengan penerimaan rata-rata sebesar Rp 21.159.420,00/Ha petani memperoleh pendapatan sebesar $\mathrm{Rp}$ 17.147.182,00/Ha. Analisis return cost ratio memperoleh nilai $>$ 1sehingga berusahatani labu kuning menguntungkan bagi petani dan hasil analisis break even point menunjukan bahwa usahatani labu kuning berada pada titik impas.

\section{Saran}

Berdasarkan kesimpulan maka dapat dikemukakan saran yaitu petani di Desa Singsingon tetap memaksimalkan dan mempertahankan produksi labu kuning serta meningkatkan keuntungan dalam berusahatani labu kuning.

\section{DAFTAR PUSTAKA}

Arsyad, L. 1999. Pengantar Perencanaan dan Pembangunan Ekonomi Daerah. BPFE. Yogyakarta.

Budiarto, S., 2011. Pemasaran Industri (Business to Business Marketing). C.V Andi Ofiset, Yogyakarta.

Hasyim, 2012. Tataniaga Pertanian. Diktat Kuliah, Fakultas Pertanian Universitas Lampung.

Hedrasty, 2011. Kandungan Labu Kuning dan Pemanfaatannya. Kanisius, Yogyakarta.
Hidayah, 2010. Manfaat dan Kandungan Gizi Labu Kuning (waluh). http://www.borneotribune.com $\{26$ Mei 2010\}.

Konore, A., 2017. Studi Komparasi Distribusi Pendapatan Petani Wilayah Berbasis Sawah dan Hortikultura di Kota Tomohon. Skripsi Fakultas Pertanian, Universitas Sam Ratulangi. Manado.

Kotler, P., 2004. Manajemen Pemasaran: Analisis, Perencanaan, Implementasi dan Kontrol. PT. Prenhallindo, Jakarta.

Munji, S., 2001. Interaksi dan Motivasi Belajar Mengajar. Jakarta: Raja GrafindoPersada. 224 hlmn.

Nurdiansyah, A., 2015. Analisis Pendapatan dan Pemasaran Kakao di Kecamatan Sekampung Udik Kabupaten Lampung Timur. Jurnal Fakultas Pertanian, Bandar Lampung.

Parini, 2012. Proses Produksi Kerupuk Labu Kuning. Jurnal Universitas Sebelas Maret, Surakarta.

Saragih, B., 2001. Agribisnis Paradigma Baru Pembangunan Ekonomi Berbasis Pertanian. Pustaka Wirausaha Muda. Bogor.

Siagian, P., 2003. Teori dan Praktek Kepemimpinan. Rineka Cipta, Jakarta.

Shinta, A., 2011. Ilmu Usahatani. Perpustakaan Nasional. Universitas Brawijaya Press.

Soekartawi, 2005. Agribisnis Teori dan Aplikasinya. Raja Grafindo Persada, Jakarta. 
,2011. Ilmu Usaha Tani. Universitas Indonesia, Jakarta.

Suprapti, L., 2005. Dasar - dasar Teknologi Pangan. Vidi Ariesta, Surabaya.

Talumepa, J., 2010. Analisis Pendapatan Petani Cengkeh di Desa Kombi Kecamatan Kombi. Skripsi Fakultas Pertanian, Universitas Sam Ratulangi. Manado.
Tjiptono, F., 2000. Manajemen Jasa. Andi, Yogyakarta.

Wijayanti, V., 2010. Usahatani Kakao dan Tingkat Ekonomi Petani di Desa Banjarasri Kecamatan Kalibawang Kabupaten Kulon Progo. Jurnal Fakultas Ilmu Sosial dan Ekonomi. Universitas Negeri Yogyakarta.

Yoko, 2012. Labu. Eley Media Komputindo, Jakarta. 